\title{
Possible Impacts of Regulating the Weekly Rest of Road Freight Drivers on Logistics in EU Countries
}

\author{
Jozef Gnap \\ University of Žilina \\ Faculty of Operation and Economics of \\ Transport and Communications \\ Department of Road and Urban Transport \\ Slovak Republic \\ e-mail: jozef.gnap@fpedas.uniza.sk
}

\author{
Dominika Beňová \\ University of Žilina \\ Faculty of Operation and Economics of \\ Transport and Communications \\ Department of Road and Urban Transport \\ Slovak Republic \\ e-mail: dominika.benova@fpedas.uniza.sk
}

\author{
Radovan Slávik \\ University of Žilina \\ Faculty of Operation and Economics of Trans- \\ port and Communications \\ Department of Road and Urban Transport \\ Slovak Republic \\ e-mail: radovan.slavik@fpedas.uniza.sk
}

Department of Road and Urban Transport

Slovak Republic
DOI 10.17818/NM/2018/4SI.18 UDK 656.1(4)

Preliminary communication Paper accepted: 28. 8. 2018.

\section{Summary}

The paper deals with the research results regarding the possible impact on the EU logistics of regulating the regular weekly rest of road freight drivers. Road freight transport is used for the large distance and the implemented changes, high fines on drivers, and carriers as well can reduce the availability of vehicles for this transport, which may have negative impact on the logistics sector, including seaports, and can cause the increased theft of shipments. The paper focuses on the major shortage of road freight drivers and the age structure of current drivers, which is a further threat to the EU logistics sector. This may have a positive impact on the increased use of the rail freight transport.

\section{INTRODUCTION}

The logistics of the 21st century is based on the planned dates of unloading and loading, i.e. on the time windows. The logistics and forwarding companies also make use of the flexibility of road freight transport on long distances. The road freight transport is used on long distances even for the container and the transport from seaports. . The reasons why containers are transported from the seaports by road freight transport are problems with the time of shipment and the delivery schedule adherence, components etc. for the needs of the automotive and electro-technical industries. The second reason is that there is insufficient capacity of rail transport infrastructure from some seaports or problems with exceeding the maximum permeability of the railway transport infrastructure on the routes to the customer [1-3]. It [1] suggests that a part of the railway transport infrastructure in the EU countries has a permeability usage over $100 \%$. This means that trains have to wait for railway lines to be released sometimes more than 24 hours. Hence transport relies on road carriers, then delivery times are "somehow" fulfilled even in case of traffic congestion on road infrastructure.

Unfortunately, changes in the EU legislation with regard to the working regime of road freight transport can significantly affect this road freight transport advantage and even reduce its available capacity and hence increase the cost of logistics.

\section{THE ISSUE OF CHANGING THE DRIVERS' WORKING TIME TAILORED TO PLANNING THE TRANSPORT}

When planning the dates of loading or unloading some logistics companies do not take into account the demands of a freight driver's working time, which is increasingly tightly controlled, particularly in the EU Member States. Some consignors, and some forwarders, do not have sufficient expertise in the road freight driver's working time and adapt to customer requirements, for example in case of the just-in-time delivery or only technological requirements for transport, with the carrier accepting the shipment order so that the time of transport will solve [4], [5].

According to the current Regulation EP and Council no. $561 / 2006$ the roadside drivers are checked in the ordinary working day and the previous 28 days. In case of inspections in the service of the carrier, they may also be inspected 12 months back from the last date of inspection. The system of controls became tightened with the introduction of digital tachographs.

It should be noted that according to the 10 paragraph 4 Regulation EP and Council no. 561/2006 firms, consignors, forwarders, tour organizers, main contractors, subcontractors and drivers' agencies shall ensure that the contractually agreed transport timetables are in accordance with this Regulation.

The knowledge of the driver's working time and its consideration in contractually agreed transport timetables should be part of the logistics staff's expertise. 
The issue of traffic planning significantly complicates the judgment of the Court of Justice of the European Union of 20 December 2017, which ruled that Article 8 (6) and (8) of Regulation (EC) No. No 561/2006 of the European Parliament and of the Council of 15 March 2006 on the harmonization of certain social legislation related to the harmonization of certain social legislation in terms ofpursuit of the business of motor vehicles is to be interpreted that a driver cannot take regular weekly rest periods in his vehicle.

This judgment allowed EU Member States to require a regular weekly rest period of at least 45 hours outside the vehicle. This judgment will have an impact on the cost of road freight, especially related to the accommodation of drivers, costs of guarded parking and changes in the transport planning particularly to those countries that have imposed high fines for breaching this judgement (Belgium, France, SRN, Great Britain, Netherlands).

There is currently a major shortage of road freight drivers in EU countries. It is not to be expected that the driver will be replaced during the weekly rest in the accommodation facility by other driver, who will continue to transport and supervise the transport cargo. How to prepare for this situation insurance companies, if the driver in the EU, under threat of high fines, expects to park the vehicle and spend at least 45 hours outside the vehicle, such as the decisions of the courts, for example, a 5-minute stay of the driver outside the vehicle, because the driver wanted to buy food and it was classified as negligence and the carrier is responsible for the theft of the consignment.

\subsection{The issue of crime in road freight transport and its impact on transport planning and taking rest of drivers}

EMEA'sstatistics concerning the road crime show that the international problem is the theft of goods from a vehicle that affects business and consumers. Organization for the protection of goods during transportation and storage and other components of logistics known as TAPA (Transported Asset Protection Association) publishes monthly Vigilant, which deals exclusively with the risks of crime during transportation [6]. This monthly journal shows how many attacks on drivers or how many attacks on vehicles occurred on the unguarded car park (Fig.1). The number of attacks in 2013 amounted to 39\%, an increase of $45 \%$ in $2014,46.25 \%$ in 2015 , a slight decrease to
41\% in 2016 and a level of $64.7 \%$ in January 2017.

There are pan-European organizations and associations, whose effort and aim is to point to the lack of sufficiently secure parking spaces by providing parking spaces that meet certain safety standards. The parking spaces are subsequently certified, presented on the website of the organizations and are provided by the carrier as a verified, approved and secure car park. Nowadays there are still problems with low numbers of parking spaces in individual countries that are verified and certified and their construction is very slow. The policy TransEuropean Transport Network (TEN-T) since the mid - 1980s has already established a policy framework for the development of infrastructure and the smooth functioning of the internal market, to ensure economic, territorial and social cohesion and better accessibility across the EU. Over the years the policy has evolved, and the first guidelines defining the TEN-T policy and infrastructure planning have been accepted.

In the case of road transport infrastructure, the following requirements are set: build the rest stops every 50 kilometres on motorways, provide sufficient capacity for parking places for business users with an appropriate level of safety and security and the availability of alternative ecological fuels [5].

ESPORG is an association of secure European car parks that creates safe car park in 15 different countries to increase safety in the transport of goods and the protection of carriers as well as in the fight against crime. It represents the first joint project, which created a network of secure parking spaces. Due to the demand from transport companies, insurers, drivers, manufacturers and authorities, ESPORG has developed the process / requirements for security certification. The certification process and self-assessment were developed in cooperation with DEKRA. Since 2016 services have been subject to audit certification. A comprehensive catalogue of criteria has been developed, which experts from DEKRA verify and the necessary software has been developed to enable the production of digital media containing images. DEKRA experts inspect items such as fencing, lighting, security equipment, entrances and exits for vehicles and people, monitoring systems, staff training and equipment, data recording and processing as well as emergency plans and measures. After a successful audit, gas stations can obtain the ESPORG certificate, which is a recognition mark with the guarantee of a minimum level of parking and

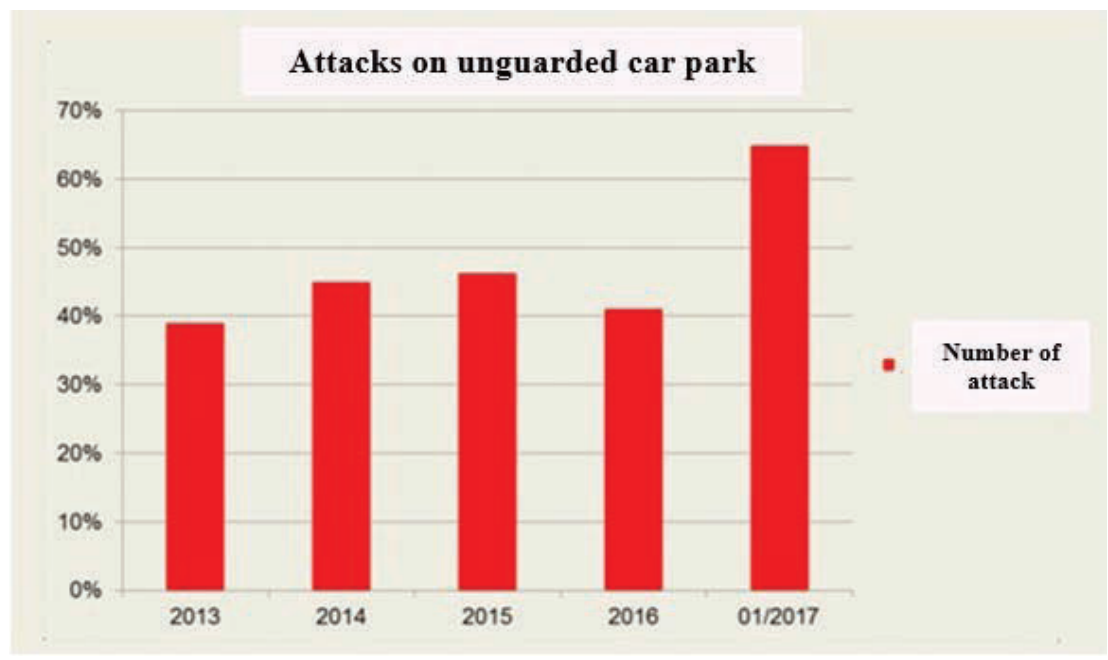

Source: authors, based on [6]

Figure 1 Share of attacks on unguarded car park in the EMEA area 
their services. The certification ensures a high standard of vehicle protection [7], [8].

TRANSPark is a web application for lorry drivers operated by the International Road Transport Union (IRU). Helps drivers and road managers easily and quickly find and add safe and comfortable parking spaces. Certified Parking spaces - These areas are considered to be the safest and most credible when designing a transport route and selecting appropriate safe parking spaces. The external company audits the parking spaces and based on the facts, further evaluates the space in the area of Safety and Convenience and gives points at the level [9].

Forwarding and logistics companies have defined in their general purchasing conditions for the provision of transport services obligations of the carrier to observe all the rules in the places of loading and unloading, regulations and safety instructions in the transport contract. For example, during shipment use only the guarded parking areas defined in the order, car parks and rest areas, which can be considered safe and when the vehicle is abandoned, there is no theft of the shipment or during the sleep of the crew members to use all the security devices in the vehicle at its disposal [10]. Customers' and insurance requirements and compliance checks to take regular weekly rest outside the vehicle will be directed to change the system of planning the work regime with an effort to restrict the use of this rest outside the State of registration of the vehicle.

In Fig. 2 is a proposal for a four-week mode of work for the road freight driver in order not to take regular weekly rest offsite (or driver's residence). However, this schedule reduces the available time capacities of drivers over a longer period, for example quarter, year.

\subsection{Research on the impact of the ban taking on weekly rest periods on logistics}

In the current shortage of road freight drivers in the EU countries, the authors made the model of the isochron availability of landing sites with a single-person vehicle crew from the selected seaports Antwerp (B), Bremerhaven (SRN), Koper (SLO) and Rijeka (HR) - Fig. 3

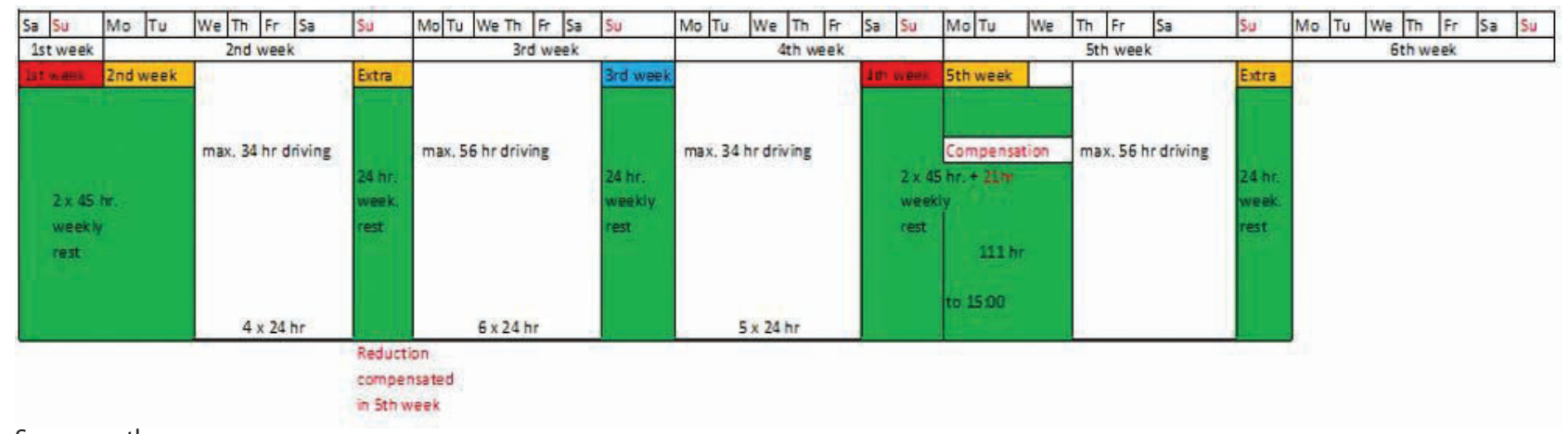

Source: authors

Figure 2 Proposal for a four-week mode of work for road freight drivers

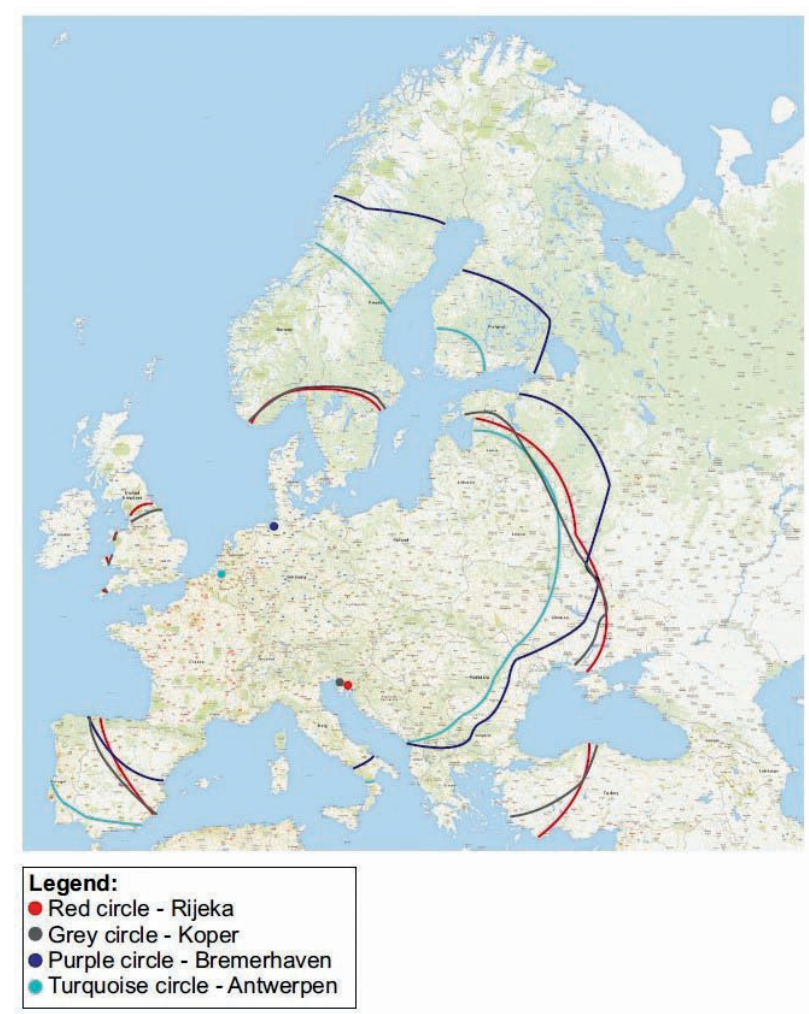

Source: authors

Figure 3 Isochronous availability of selected seaports without taking regular weekly rest in the vehicle 
We start from the fact that the driver is used in port service for the first week 56 hours, and for the possible depletion of rail infrastructure capacity, driver is deployed on the second week for long-haul shipments.

Calculation of availability of isochron:

$$
\mathrm{ID}=\frac{T D V}{V}=\frac{D C V-C V 1 T(\max 56 \mathrm{~h})}{V}[\mathrm{~km}]
$$

where:

- TDV - the remaining weekly driving time of the vehicle [hrs]; must always be less than 56 hours,

- $\quad$ V - average speed of the lorry on the assumed transport route $[\mathrm{km} \cdot \mathrm{h}-1]$

- DCV- two-week driving time (maximum 90 hours) [hour],

- CV1T - actual driving time for the first week [hour].

In constructing the isochrones of availability in Fig. 3, we consider the average speed to be $60 \mathrm{~km} / \mathrm{h}$ and the time needed to drive from the port and return together 34 hours. So it was assumed that the driver had the maximum allowed time of 56 hours for the first week. In some weeks, transport planning may be severely affected by truck driving bans, which depend on transport destinations.

Tab. 1 assesses the availability of certain European cities from selected ports on the basis of the proposed procedure for calculating the availability of isochrons by road freight without requiring regular weekly rest in the vehicle.

\section{ISSUES OF SHORTAGE OF DRIVERS AND FUTURE CAPACITIES OF ROAD FREIGHT TRANSPORT}

The governments of the EU Member States, as well as the European Commission, are planning for continued economic growth and hence an increase in Gross Domestic Product (GDP). Research shows that transport performance in freight transport in tonne-kilometres from GDP growth [11-14]. How is the road freight transport sector prepared, also in terms of legislative interventions by the EU as well as by individual EU Member States.

The total number of lorries in the countries surveyed increased by more than 2.3 million for 2010-2015 (excluding Turkey by about 1.5 million). The biggest increase was in Turkey by 885874 vehicles in Poland (by 331376 vehicles) and in Germany (by 316333 vehicles). Some EU countries have a different tax burden, which in part affects the number of vehicles [13]. On the other side, those countries that have experienced a significant drop in lorries, Spain, have a reduction of up to 252462 .

Table 1 Availability of some European cities from selected ports after 34 hours of driving (back and forth)

\begin{tabular}{|l|c|c|c|}
\hline City/Port & Antwerp & Bremerhaven & Koper \\
\hline Athens & No & No & Yes \\
\hline Berlin & Yes & Yes & Yes \\
\hline Hamburg & Yes & Yes & Yes \\
\hline Helsinki & Yes & Yes & Yes \\
\hline London & Yes & Yes & Yes \\
\hline Madrid & Yes & No & Yes \\
\hline Marseille & Yes & Yes & Yes \\
\hline Oslo & Yes & Yes \\
\hline Paris & Yes & Yes & No \\
\hline Rome & Yes & Yes & Yes \\
\hline Rotterdam & Yes & Yes & Yes \\
\hline
\end{tabular}

Source: authors

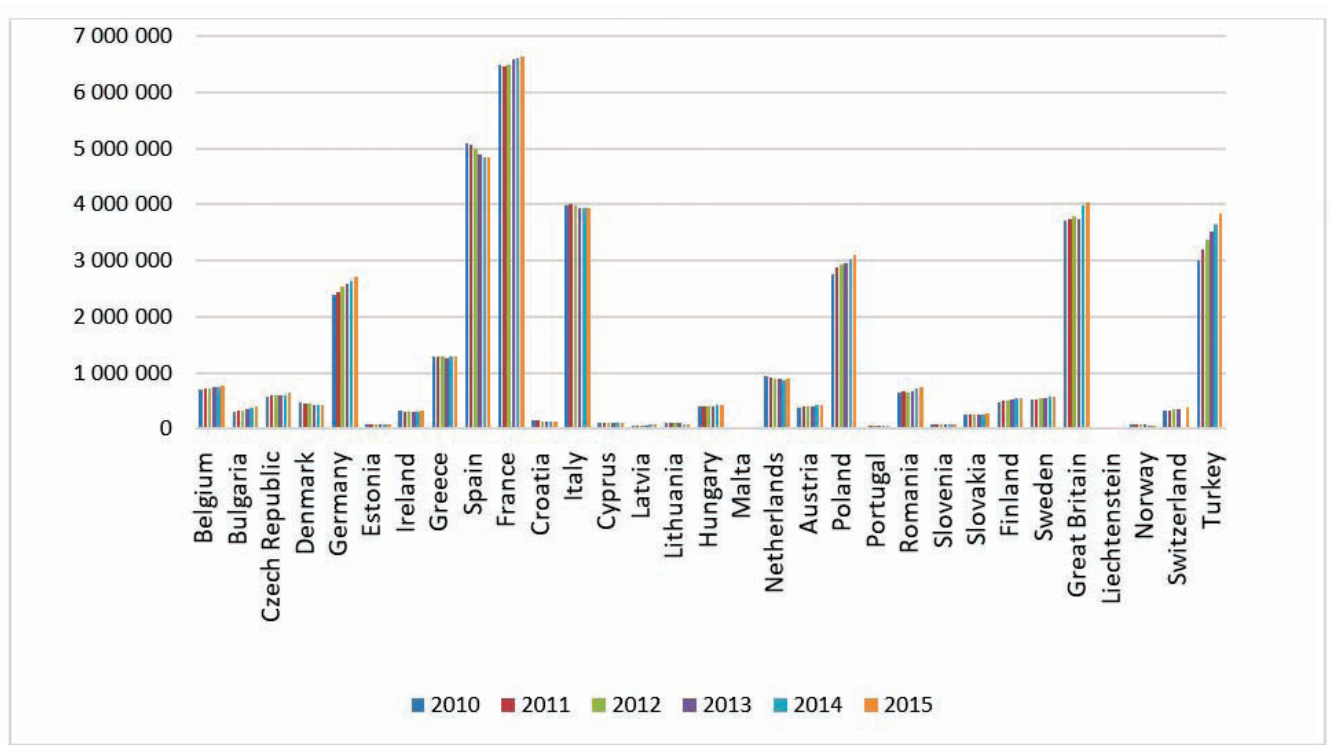

Source: authors, based on Eurostat

Figure 4 Evolution of the number of lorries in selected European countries 


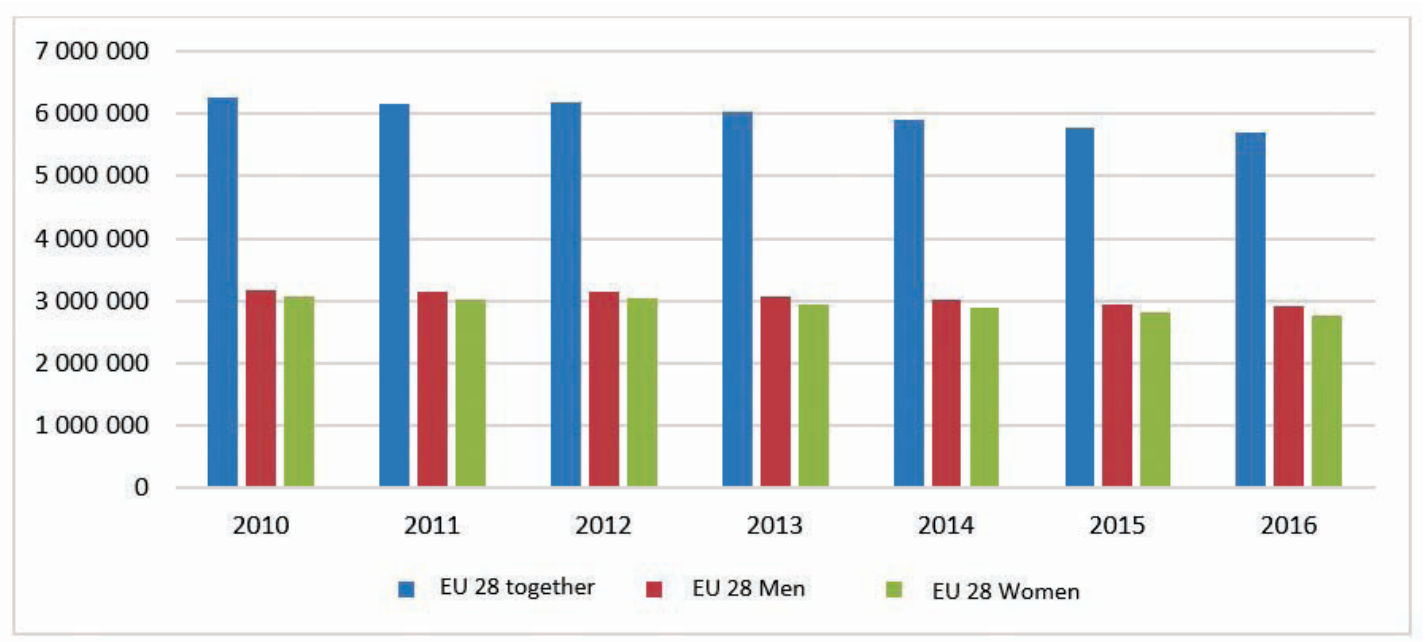

Source: authors, based on Eurostat

Figure 5 Development of population growth in the 21 years of age in the EU 28 from 2010 to 2016

Will the EU have a sufficient number of drivers for this growing number of vehicles and the growing demand for road freight transport? The EU and some Member States' restrictive measures affect the number of drivers, especially international road transport. The impact of demographic developments on the number of drivers is also significant. In FIG. 5 is the evolution of the population of the EU at the age of 21 with the division between men and women. The age of 21 years has been targeted by the authors, because currently, for motor vehicles $C$ and CE (vehicles intended for the carriage of goods weighing over 3.5 tons), such age is required.

Figure 6 shows a relatively significant decline in the 21-year age bracket for the period 2010 to 2016 in Germany, Spain, France but also in Poland, Romania, Greece and Bulgaria. An increase in the number of this category of men of "potential" new road freight drivers is recorded only for Turkey, which is not an EU Member State. Based on demographic developments, no improvement can be expected. The real need for road freight drivers in relation to their age composition is even higher (see Figure 7).

There is a lack of more than 1900 drivers in the category of road lorries drivers (driving licence group C) in Slovakia. The situation in the category of bus transportation drivers (driving licence group D), according to their age criterion, is even worse. IRU (International Road transport Union) has been pointing to this problem for a longer time.

The issue of absence of the road lorry drivers in GB is emphasised for longer time by the FTA - Freight Transport Association. Problematic would be the period when the drivers at age 45-59, who are according to the UK statistics the largest group, will start to retire and will not be replaced by new drivers. Similarly the Volvo Group published their study about absence of the road lorry drivers in Australia. This means that the problem in this domain is not bounded by borders of Europe.

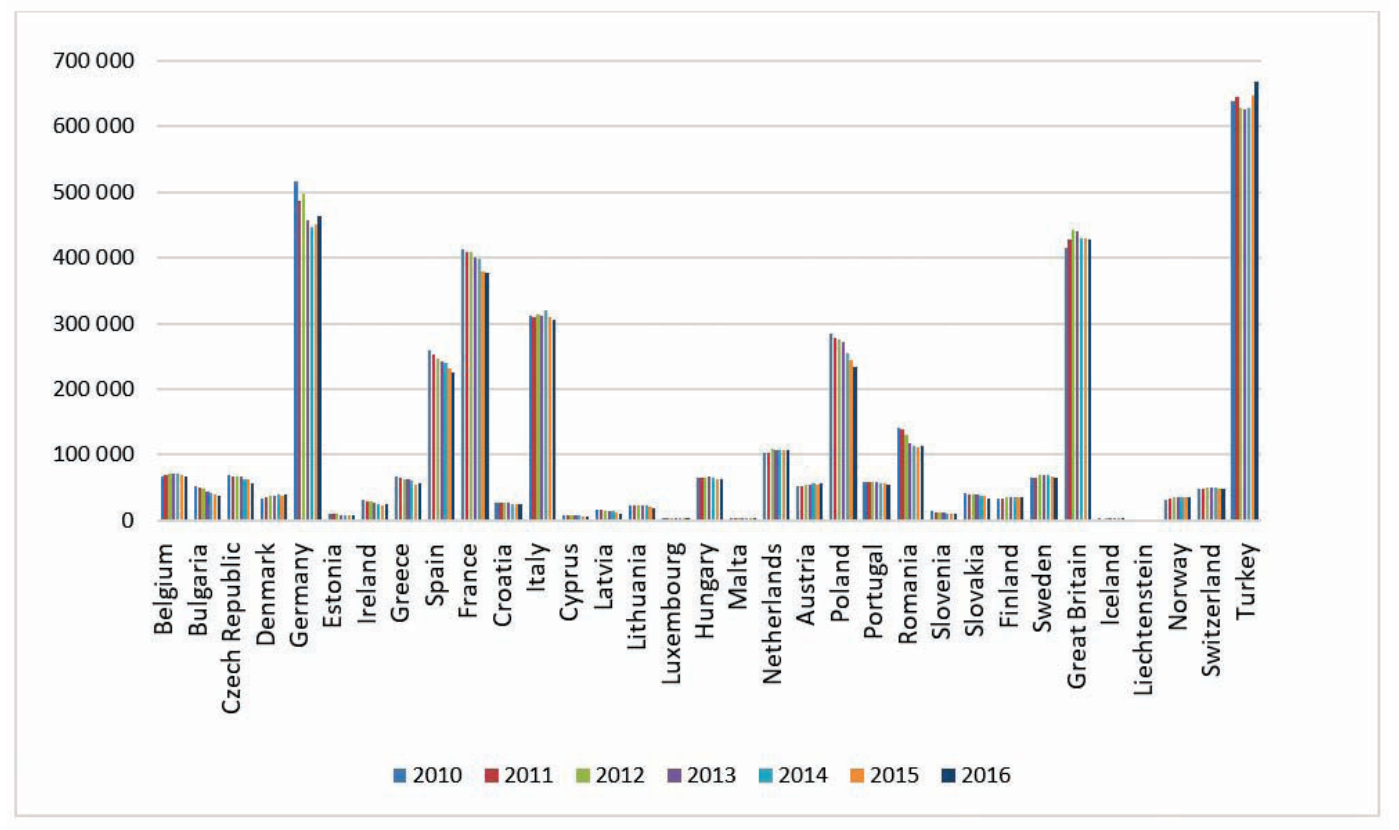

Source: authors, based on Eurostat

Figure 6 Developments in the number of 21-year-olds (potential new drivers) in selected countries between 2010 and 2016 


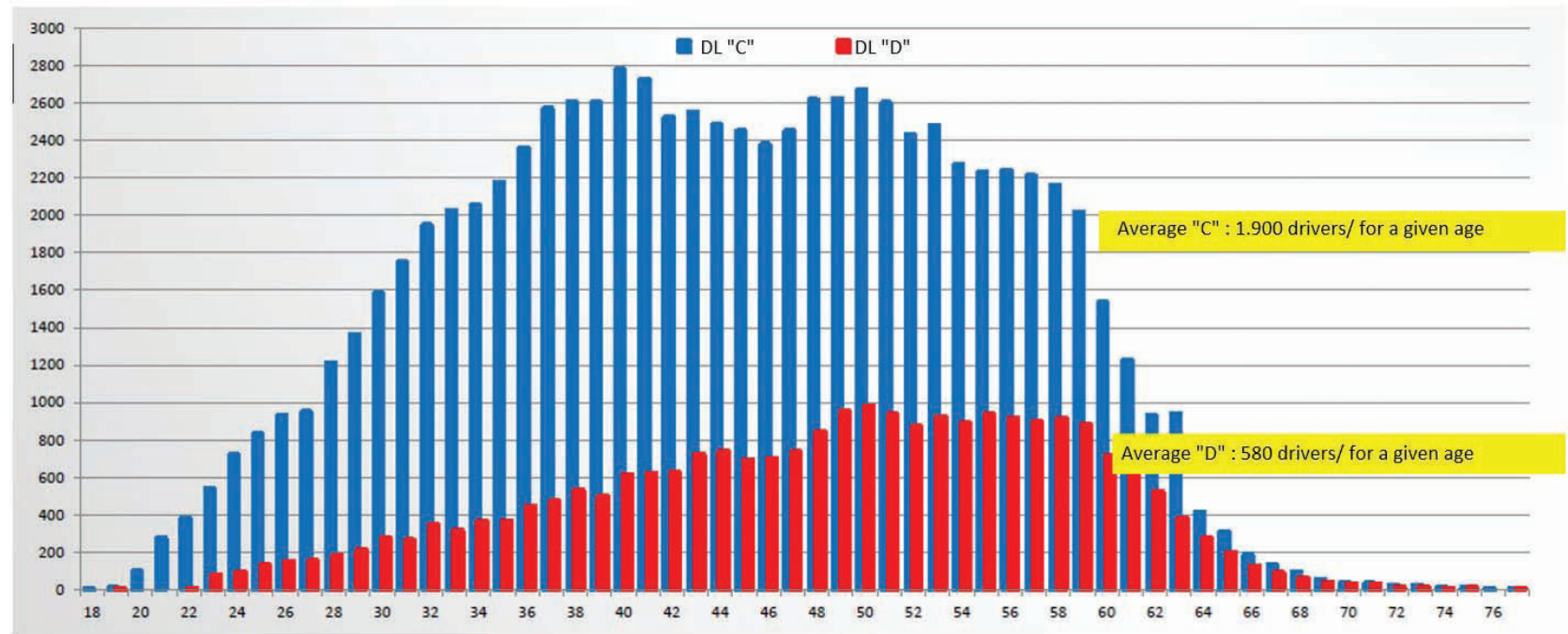

Source: Ministry of Transport and Construction, 2017

Figure 7 Number of drivers in the appropriate age category and driving license in the Slovak Republic

Will the logistics sector be able to respond to this situation and will it increase the usage of rail freight transport in accordance with the intentions of the EU's White book in the field of transport? If more rail freight transport is used, the logistics sector will also contribute to protecting the environment [16], [17].

\section{CONCLUSION}

The decision of the Court of Justice will cause that the available time capacity of drivers will decrease and so will the total offer of road freight transport in the EU countries in case that there will be tendency to form the transport schedules so to avoid taking a regular weekly rest ( 45 hours) in those countries which have introduced high penalties for the drivers on one side and also for the forwarders on the other side. All this will cause the increased transport costs. This fact is already visible in the transport destination France, where the offer of road forwarders has significantly reduced due to the high penalties, to the introduction of minimum wage and related administrative measures. Maybe there is offer as a solution to this problem to deploy two-person crews to enable to form the transport schedules so to do not have to take regular weekly rest in the countries which are charging it (Belgium, Germany, France, GB and Netherland). This kind of solution is in the most transports unreal because of the acute deficiency of road transport drivers.

Another solution is to ensure taking of regular weekly rest ( 45 hours) of the driver outside the vehicle. Current regulation of EP and the Council 561/2006 does not address where the driver should take his weekly rest. On the other side the driver should leave the vehicle for 45 hours. The decisions of the courts of the past said that even when the driver left the vehicle for 5 minutes and in that time came to the robbery of transported goods, the forwarder is fully responsible for that loss. Therefore, it was pointed out in the post, that in EU countries we do not have enough secured parking facilities, which could also provide accommodation for drivers and at least partially help solvethis problem.

In real transport, when the forwarder would fulfil all requirements of EU legislation, the CMR convention, insurance companies and customers, the forwarder will have to plan the transport schedules more exact and will have to book free spaces at secured parking places, which provide the accommodation, in advance as there is a lack of such stops. On certain road sections and at the current number of road shipments there may occur the absence of secured parking places, which could have impact on the transport schedule itself. The fact that the driver must leave the planned route and drive to the secured parking places or to go round the risky road sections leads to increasing of total driving performance of vehicle and the time of transport and also related costs. Also the fees for using secured parking places could be related to this. The impacts can be observed on increasing travel allowances and wages that have to be paid to the driver by law. An amendment to the Regulation of EP and the Council 561/2006 on the harmonization of certain social legislation relating to road transport is under preparation, which will have to reflect the decision of the Court of Justice. It should be noted that the European Commission did not prepare an impact study on the logistics sector, industry, parking facilities on road infrastructure, production enterprises and logistics warehouses in EU countries if the driver's regular weekly rest is required outside the vehicle. Also the insurance companies have not prepared such products that could cover the losses of consignments from the abandoned vehicles when the carrier complied with the binding prescription of the EU. For newlyregistered vehicles in EU countries it should be noted, if from March 2019 the digital tachographs would be connected with Global navigation system (GNSS), that the need for accurate planning and adherence to road haulage schedules will become even more current.

The post pointed out to the selected aspects of this issue which currently require constant attention. The EU should not take decisions that are not supported by scientific studies of the impact of these decisions. Unfortunately, only now the studies on the lack of drivers are starting to be processed from the side of IRU, Volvo Trucks, and the association of carriers.

\section{Acknowledgement}

This post was created thanks to support under the Operational Program Research and Development for the project:

Excellence Centre for Intelligent Transport Systems and Services 


\section{II., ITMS 26220120050 co-financed by the European Regional Development Fund}

\section{REFERENCES}

[1] Study on Infrastructure Capacity Reserves for Combined Transport by 2015, Kombiconsult, Kessel + Partner Transport consultant, Prepared for International Union of Railways Combined Transport Group (UIC-GTC), Freiburg/Frankfurt am Main/Paris, 2015.

[2] Stopka, O., Chovancová, M., Kampf, R. Proposal for Streamlining the Railway Infrastructure Cypacity on the Specific Track Sektion in the Context of Establishing an Integrated Transport System. Matec Web of Conferences, 2017, 134, pp. 1-8. DOI: 10.1511/matecconf/201713400055.

[3] Kendra, M., Masek,J., Ponicky, J., Skrucany, T. Proposal of methodology for calkulation the quantity of validation machines in railway transport, Transport Research Procedia, 2016, Vol. 14, 2016, pp. 1977-1986. https://doi. org/10.1016/j.trpro.2016.05.165

[4] Vrabel, J., Jagelcak, J., Zamecnik, J., Caban, J. Influence of Emergency Braking on Changes of the Axle Load of Vehicles Transporting Solid Bulk Substrates, Procedia Engineering, 2017, Vol. 187, pp. 89-99. Transportation Science and Technology: Proceedings of the 10th International Scientific Conference, TRANSBALTICA 2017. https://doi.org/10.1016/j.proeng.2017.04.354

[5] Kubasakova, I., Jagelcak, J. Logistics system just-in-time and its implementation within the company. Communications: scientific letters of the University of Žilina, 2016, Vol. 18, No. 2, pp. 109-112. ISSN 1335-4205.

[6] TAPA EMEA. Vigilant Journal. [online]. Available via: http://www.tapaemea. org/information/newsletter-vigilant.html.

[7] European Comission. Mobility and Transport. [online]. Available via: http:// ec.europa. eu/transport/infrastructure/tentec/tentec-portal/site/en/maps.html.
[8] Asociation ESPORG. Dostupné na internete: http://www.esporg.eu/what-wedo/intelligent-transport-systems/.

[9] TRANSPark SW. [online]. Available via: https://www.unece.org/fileadmin/ DAM/trans/doc/2013/ac11/Presentation_06.pdf.

[10] Gnap, J., Rovňaníková, D., Rakovanová, R., Dvoryadkina, E.B. The Problems of Planning a Timetable for Transport by Road in Terms of Theft Protection. LOGI - Scientific Journal on Transposrt and Logistics, 2017, Vol. 8, No. 1, pp.28-37. https://doi.org/10.1515/logi-2017-0004

[11] Gao, Y. et al. Study on Relationship Between Comprehensive Transportation Freight Index and GDP in China. In: Procedia Engineering, 2016, Vol. 137 Elsevier, pp. 571-580.

[12] Jakubík, P., Kerimkhulle, S., Teleuova, S. How to Anticipate Recession via Transport Indices. Journal of Economics, 2017, Vol. 65, No. 10, pp. 972-990. ISSN 0013-3035.

[13] Varjan, P, Rovňaníková, D., Gnap, J. Examing Changes in GDP on hhe Demand for Road Freight Transport. Procedia Engineering, 2017, Vol. 192, pp. 911-916. DOI: 10.1016/j.proeng.2017.06.157.

[14] Pupavac, D., Krpan, L., Maršanić, R. The effect of subsidies on the offer of sea transport. Our Sea, 2017, Vol. 64, Issue 2, pp. 54-57.

[15] Konečný, V, Gnap, J., Šimková, I. Impact of fiscal decentralization on motor vehicle taxation in the Slovak republic. Transport and Telecommunication, 2016, Vol. 17, No. 1, pp.28-39. https://doi.org/10.1515/ttj-2016-0004

[16] Gnap, J., Kalašová, A., Gogola, M., Ondruš, J. The Centre of Excellence for transport service and control. Communications, 2010, Vol. 12, No. 3A), pp. 116-120.

[17] Skrúcaný, T., Kendra, M., Sarkan, B., Gnap, J. Software Simulation of an Energy Consumption and GHG Production in Transport, Tools of Transport Telematics, 2015, Vol. 531, pp.151-160. https://doi.org/10.1007/978-3-319-24577-5_15 